\title{
THE EFFECT OF ALKALI ON THE ABSORPTION OF A PEPTIDE OF THYROXINE FROM THE GASTRO- INTESTINAL TRACT
}

\author{
By WILLARD O. THOMPSON, SAMUEL B. NADLER, PHEBE K. THOMP- \\ SON AND LOIS F. N. DICKIE
}
(From the Department of Medicine, Rush Medical College of the University of Chicago, the Department of Biochemistry, Tulane University, New Orleans, and the Presbyterian Hospital, Chicago)

(Received for publication July 23, 1934)

When pure thyroxine suspended in distilled water is administered by mouth it has only a slight effect on the basal metabolism (1). However, if pure thyroxine is dissolved in an excess of sodium hydroxide (presumably forming the disodium salt of thyroxine (2)) and is then administered by mouth, there is a well-marked increase in the basal metabolism which, on the average, is 63 per cent as great as the increase which follows the intravenous administration of thyroxine in the same form $(3,4)$. If the monosodium salt of thyroxine (tablets) is administered by mouth, the increase in basal metabolism is only 22 per cent as great as that which follows the intravenous injection of an equivalent dose of thyroxine in alkaline solution $(1,5)$. Thus an alkaline solution of thyroxine is nearly three times as effective, on the average, as an equivalent dose of the monosodium salt when both compounds are administered by mouth. Furthermore, it has been noted that the increase in basal metabolism produced by the oral administration of single large doses of thyroxine in alkaline solution is, on the average, about the same as that produced by single large doses of desiccated thyroid containing the same amount of iodine $(6,7)$.

By proteolytic digestion of thyroid, Harington and Salter (8) obtained a peptide of thyroxine which they state has " a much wider range of solubility" than thyroxine and contains thyroxine in a levorotatory form. Salter, Lerman and Means (9) have recently reported that this peptide had about the same effect whether given orally or intravenously and that it had the same effect as racemic thyroxine when both were administered intravenously in doses which contained the same total amounts of iodine. They have kindly informed us that, for oral administration, their peptide "was dissolved in sodium hydroxide" and the solution "then neutralized with phosphoric acid."

It seemed desirable to compare the effect of oral administration of this peptide with that of an equivalent amount of thyroxine in alkaline solution. 
Accordingly, one of us (S. B. N.) prepared a similar substance by the method of Harington and Salter (8), using double the concentration of enzymes employed by them, i.e. 1.0 per cent pepsin and 0.4 per cent trypsin. From 1620 grams of desiccated thyroid ${ }^{1}$ there were obtained $310 \mathrm{mgm}$. of a light buff colored powder containing 48 per cent iodine by the method of Leland and Foster (10) and 2.5 per cent total nitrogen by the micro$\mathrm{K}$ jeldahl method, giving a nitrogen: iodine ratio of $0.48: 1$. Before hydrolysis, 43 per cent of the total nitrogen was found to be in the amino form by the method of Folin (11); and, after six hours hydrolysis by the method of Harington and Salter (8), 78 per cent was found to be in this form. Most of the digestion products obtained by Harington and Salter contained from 45 to 50 per cent iodine and 5 per cent nitrogen, giving a nitrogen: iodine ratio of $1: 1$, but two of their products gave nitrogen: iodine ratios of $0.6: 1$. The product used by Salter, Lerman and Means (9) contained 49 per cent iodine and 3.3 per cent nitrogen, giving a nitrogen : iodine ratio of $0.6: 1$. When subjected to the action of nitrous acid and made alkaline with ammonia, the product we obtained gave an orange pink color in contrast to the red pink color which is characteristic of thyroxine. When it was dissolved in $\mathrm{N} / 10$ sodium hydroxide, the solution had a slight yellow tinge. In order to eliminate the possibility that it contained acid-soluble iodine, a small amount was dissolved in alkaline solution and precipitated at $\mathrm{pH} 5.0$ by the cautious addition of dilute hydrochloric acid. Since 95 per cent of the iodine was recovered in the precipitate, it seemed logical to conclude that diiodotyrosine and inorganic iodine were both absent. From these data it would appear that our product is similar to the thyroxine peptide described by Harington and Salter.

Our peptide, like pure thyroxine, was insoluble in distilled water but was soluble in alkali. In view of this similarity in solubility it seemed all the more desirable to compare the calorigenic effects of oral administration of the two substances, (a) when suspended in distilled water, and (b) when dissolved in alkaline solution.

\section{METHOD}

The observations were made on three patients with well-marked myxedema. In the second patient the myxedema was spontaneous and in the other two it followed a subtotal thyroidectomy for exophthalmic goiter. Parts of the data (exclusive of those on the peptide) have been published elsewhere, as collected, to illustrate other points $(1,3,7)$. The SanbornBenedict machine was used in the determinations of basal metabolism and

${ }^{1}$ The desiccated thyroid, pepsin and trypsin used in the preparation of this substance were very kindly supplied by Dr. Klein of the Wilson Laboratories, Chicago. 
Aub-DuBois standards in the calculations. The number of calories produced by each type of treatment ("excess calories") has been calculated by a method previously described $(3,12)$. The synthetic thyroxine used was the crystalline powder purchased from Hoffmann-La Roche. The monosodium salt of synthetic thyroxine was bought from the same manufacturers in the form of tablets, each of which contained $1.03 \mathrm{mgm}$. of the salt.

\section{DATA}

The data are recorded in Charts 1 to 3 and summarized in Tables I and II. To facilitate comparisons in the tables, the effects of thyroxine have been calculated in terms of $10 \mathrm{mgm}$. (6.5 mgm. of iodine) and the effects of the peptide in terms of $13.5 \mathrm{mgm}$. (6.5 mgm. of iodine). It may be seen from Table I that, regardless of whether the effects of the various types of treatment are compared on the basis of the amount of increase in the basal metabolism or on the basis of the number of calories produced, similar conclusions are arrived at for the three patients in this study. Therefore, for the sake of simplicity, in discussing the data we shall confine our attention almost entirely to the amount of increase in the basal metabolism.

It may be noted that when the peptide was given by mouth suspended in distilled water, it had only about one-third as much effect as when it was given in alkaline solution. Thus, by calculation, the average increase in basal metabolism for a dose of $13.5 \mathrm{mgm}$. containing $6.5 \mathrm{mgm}$. of iodine was from minus 31 per cent to minus 22 per cent when the peptide was given suspended in distilled water and from minus 32 per cent to minus 7 per cent when it was given in alkaline solution. These increases in metabolism are nearly the same as those produced respectively by the oral administration of the monosodium salt of thyroxine in tablet form (from minus 33 per cent to minus 23 per cent, on the average) and by the oral administration of thyroxine in alkaline solution (from minus 32 per cent to minus 10 per cent, on the average) in doses which contained the same amounts of iodine. No adequate explanation can be offered for the similarity in the effect of oral administration of the peptide suspended in distilled water and that of the monosodium salt of thyroxine. It would appear that the peptide, when given suspended in distilled water, is absorbed as well as the monosodium salt in tablet form. If absorption depends upon the formation of a soluble salt in the small intestine, then it must follow that the peptide forms a soluble salt in this portion of the gastro-intestinal tract with greater ease than pure thyroxine, because, in the same dose by mouth, thyroxine as the free amino-acid does not produce a definite effect on the basal metabolism (1). It is possible that the effect of administering the peptide by mouth in an alkaline solution is slightly greater than that of administering thyroxine by mouth in an alkaline solution, but the data are not extensive enough to settle this point. 


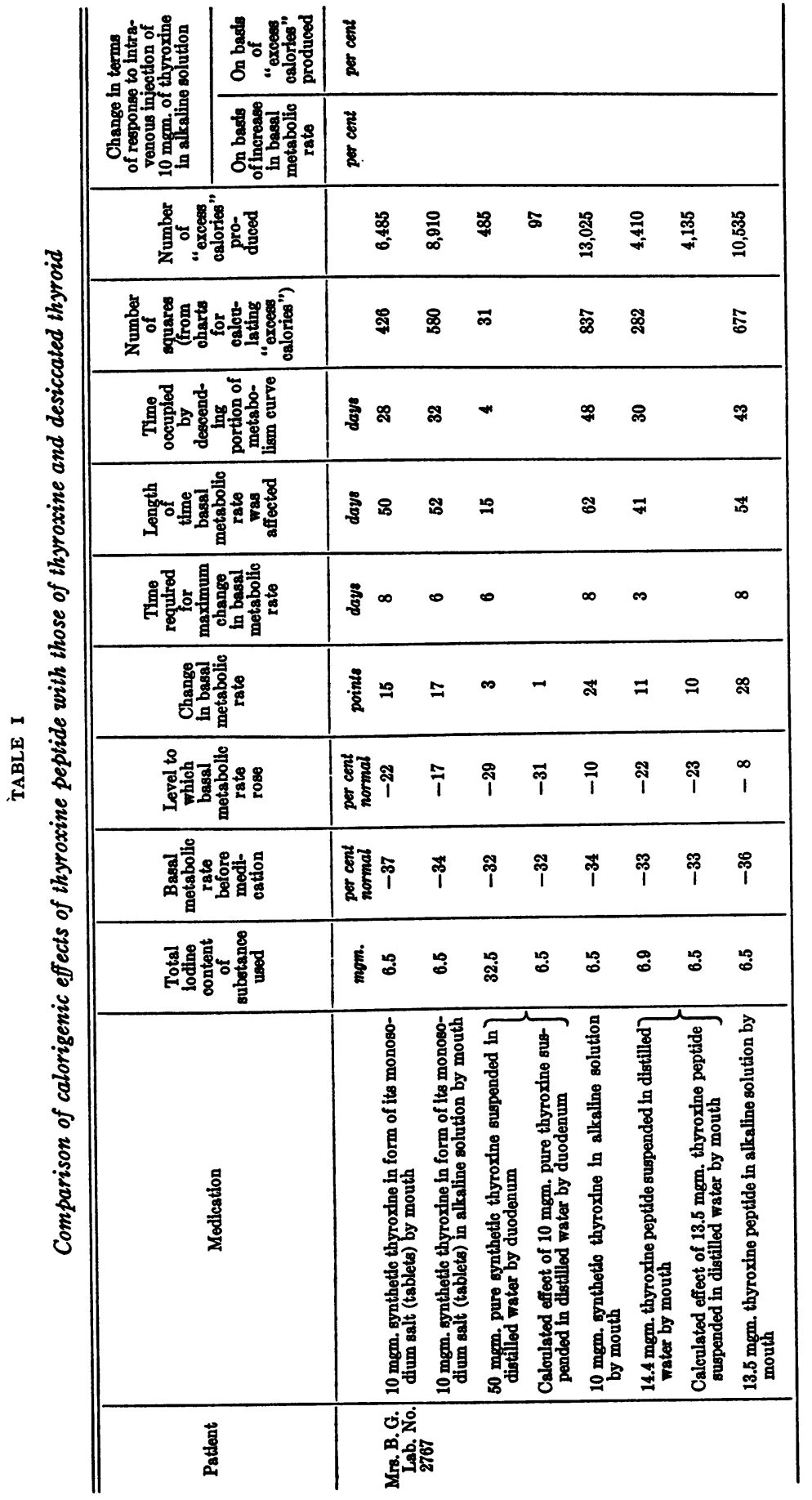


W. THOMPSON, NADLER, P. THOMPSON AND DICKIE

\begin{tabular}{|c|c|c|c|c|c|c|c|c|c|c|c|}
\hline \multirow{2}{*}{ 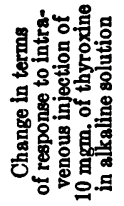 } & 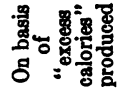 & $\begin{array}{l}\text { है } \\
\text { s }\end{array}$ & & 8 & §̊ & $\overrightarrow{0}$ & \multicolumn{3}{|c|}{ ๑ } & ฉి & \multirow[t]{2}{*}{8} \\
\hline & 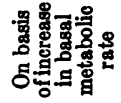 & $\begin{array}{l}\vec{E} \\
5\end{array}$ & & క్రి & $\widehat{ล}$ & $\bar{\infty}$ & & $\mathscr{8}$ & & ஜ & \\
\hline 兽。 & & 罟 & ళ్ల్య & 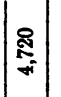 & 总 & $\underset{7}{\stackrel{0}{9}}$ & 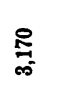 & 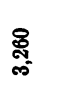 & 总 & $\stackrel{\substack{0 \\
-}}{-1}$ & 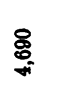 \\
\hline 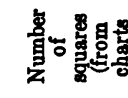 & 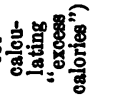 & 号 & ริำ & & ฐั & శ్లొ & $\stackrel{\infty}{\sharp}$ & & $\Xi$ & & 焗 \\
\hline 思鄫。 & 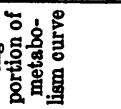 & క్ํำ ส & $=$ & ริ & $\exists$ & $\ddot{N}$ & ঞ & & $=$ & & $\vec{a}$ \\
\hline 勇。 & 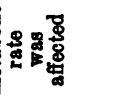 & క్్ำ & \& & ฉ & ผั & ๓ & $\mathscr{m}$ & & ลิ & & $\vec{\varpi}$ \\
\hline 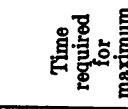 & 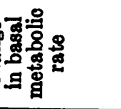 & క్ & $\omega$ & $\infty$ & $\infty$ & 0 & $\boldsymbol{N}$ & & $\sim$ & & $N$ \\
\hline & & 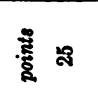 & 9 & สี & $\infty$ & ลิ & $\stackrel{2}{\longrightarrow}$ & $\approx$ & $\infty$ & $\infty$ & สี \\
\hline & & 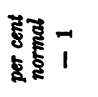 & $i$ & $\infty$ & $i$ & $i$ & $\bar{i}$ & $\overline{1}$ & $\hat{1}$ & $\stackrel{\infty}{1}$ & $i$ \\
\hline 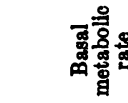 & & 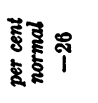 & ָ̊ & aึ & คึ & ণิ & ণ̊ & ণึ & ণิ & ণ̊ & ণ্ \\
\hline 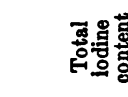 & & है & : & 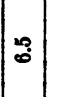 & $\stackrel{\infty}{\infty}$ & $\ddot{0}$ & $\mathscr{\wp}$ & $\because$ & $\stackrel{9}{0}$ & $\because 0$ & 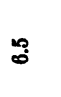 \\
\hline & & 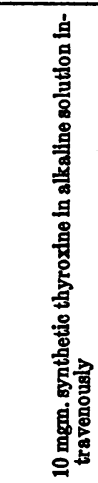 & 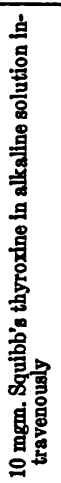 & 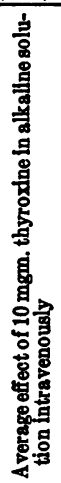 & 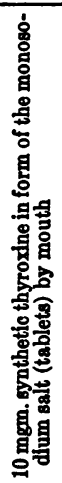 & 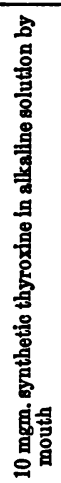 & 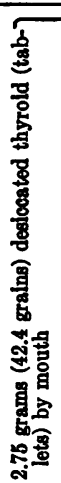 & 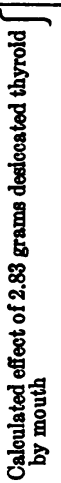 & 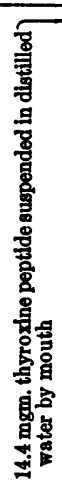 & 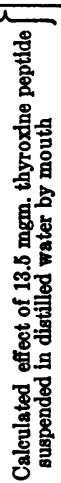 & 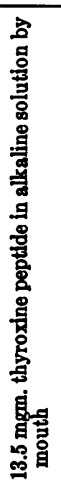 \\
\hline & & 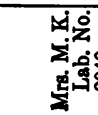 & & & & & & & & & \\
\hline
\end{tabular}


PEPTIDE OF THYROXINE

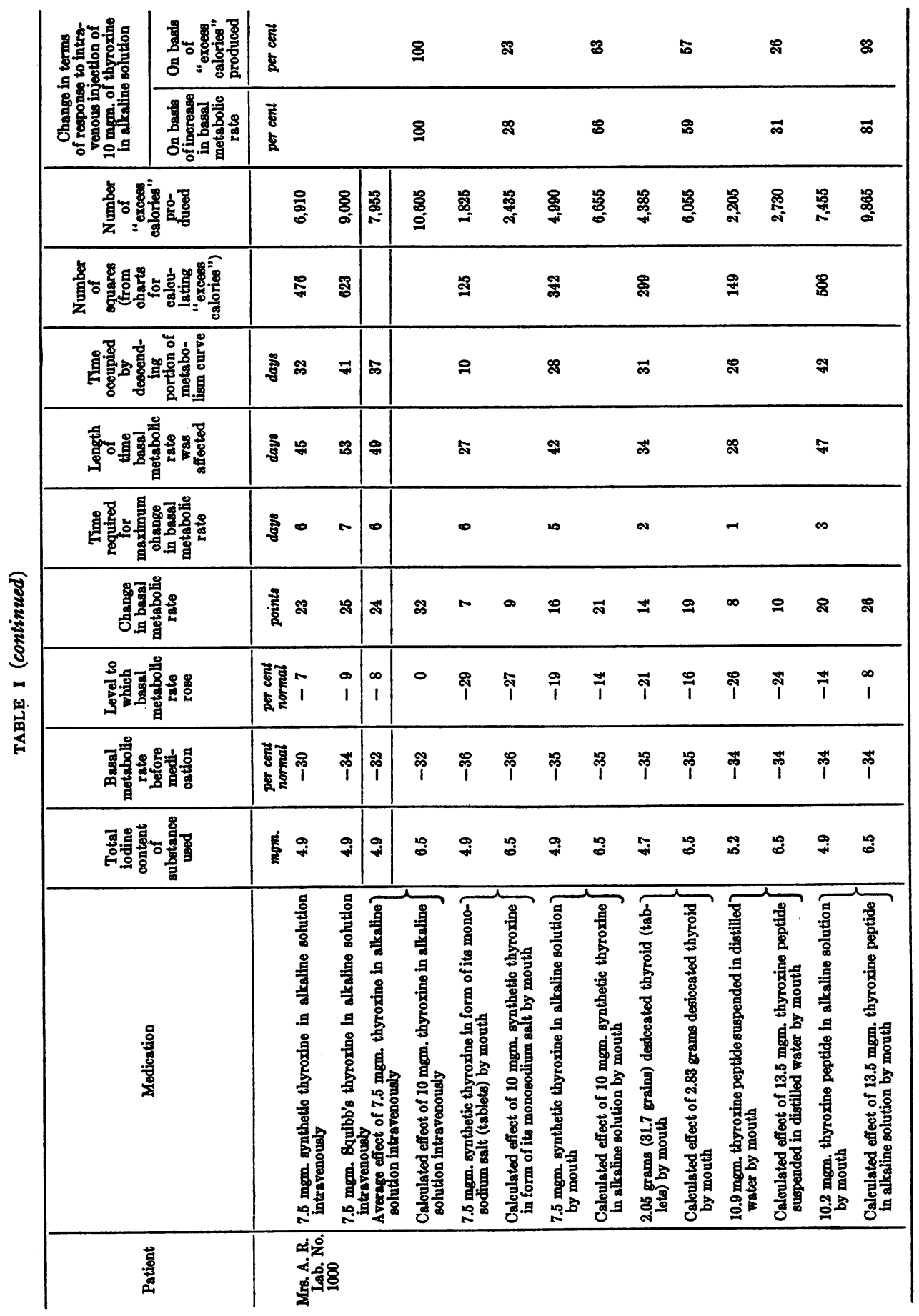


W. THOMPSON, NADLER, P. THOMPSON AND DICKIE

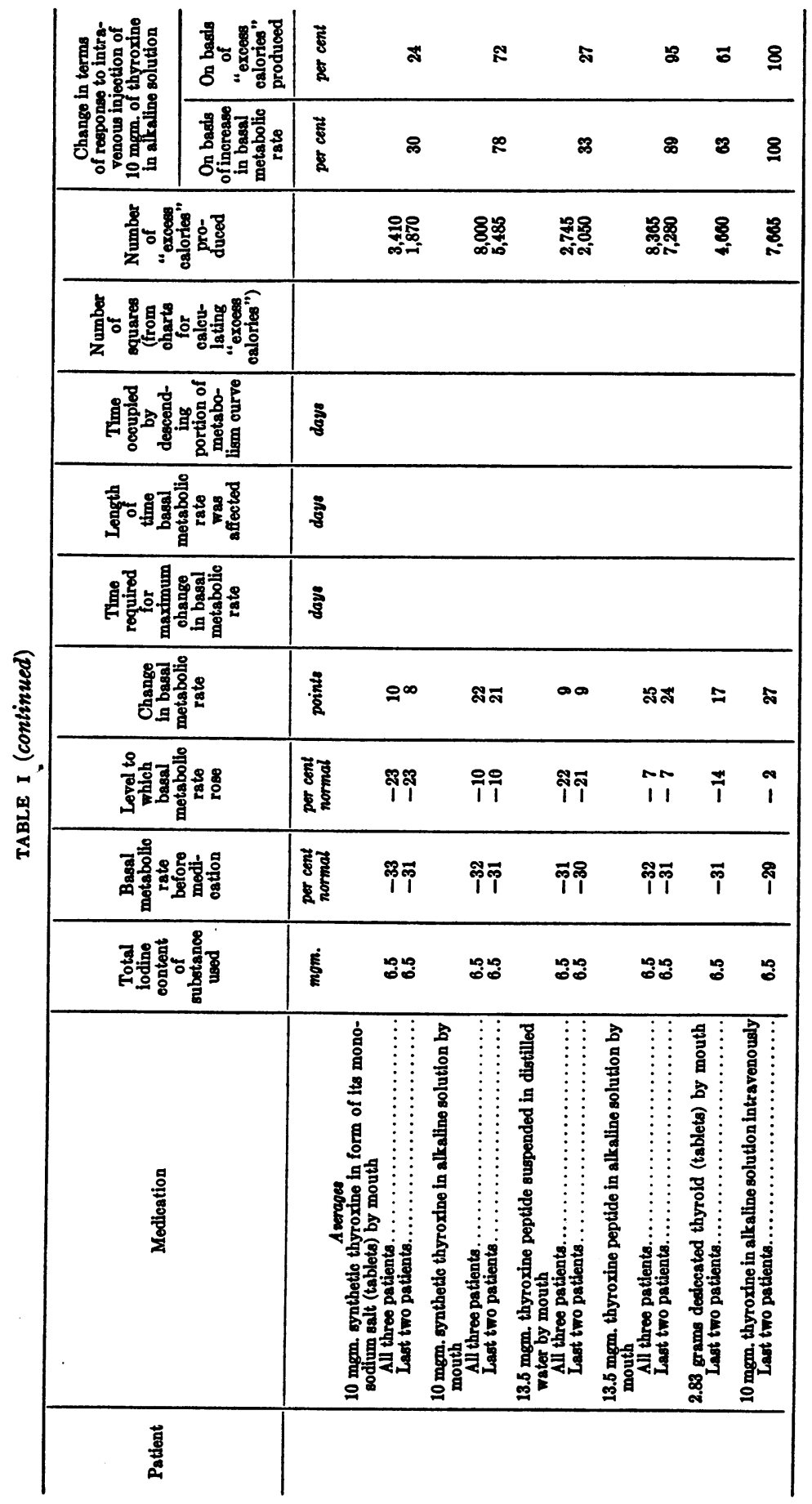




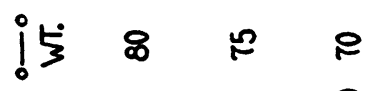

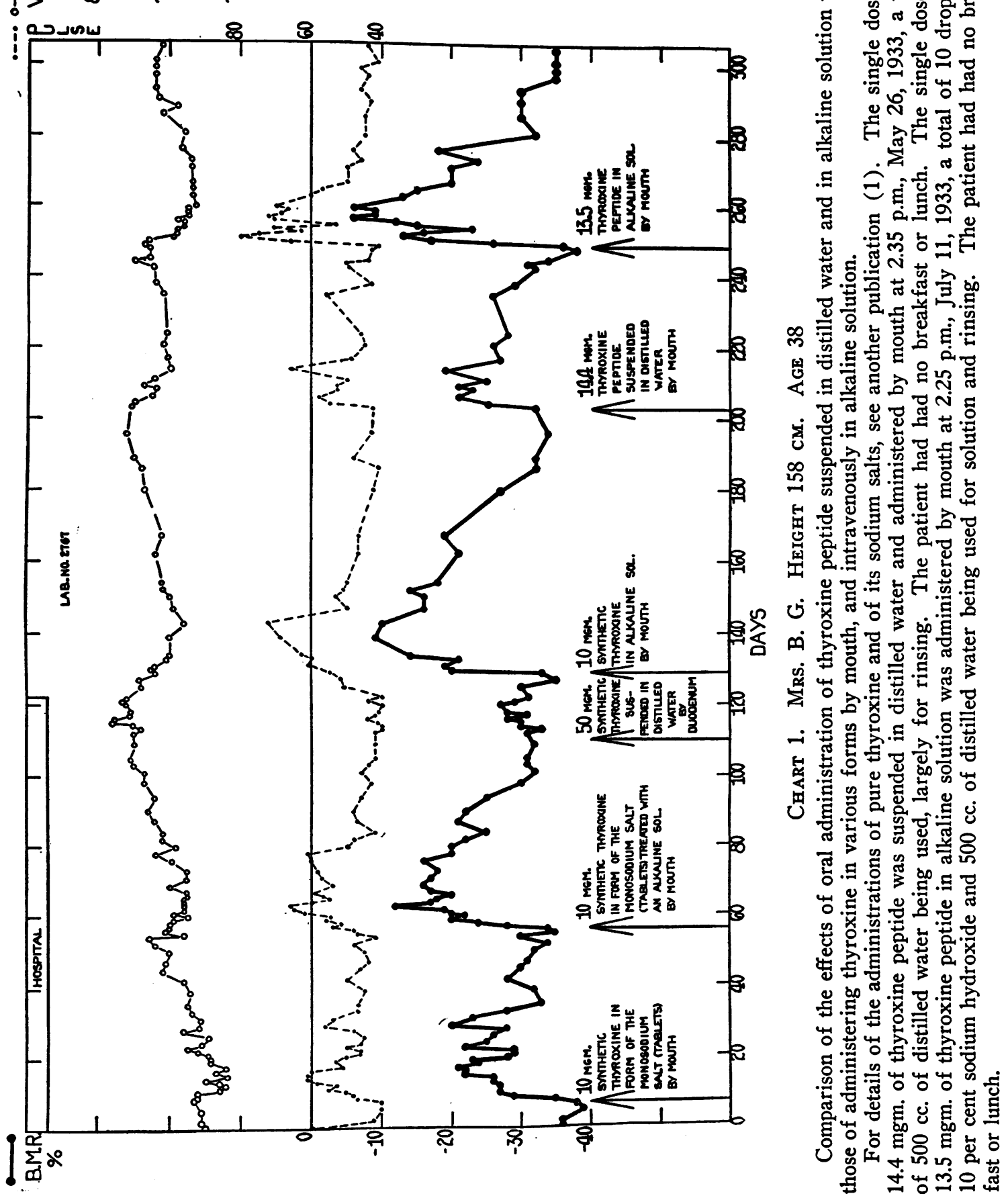








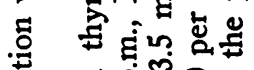
$\exists$ 혀의의

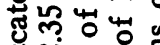

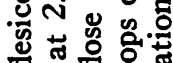

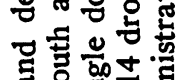

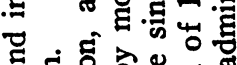

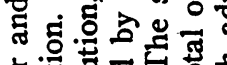

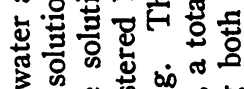

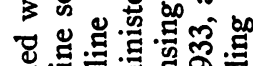

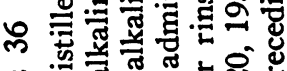
ติํำ < .. .5 .5 品

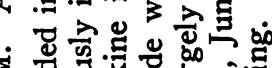

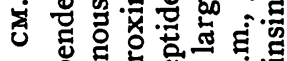
is क 풍 영영 出

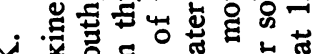

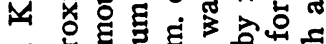

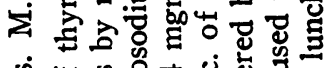

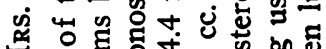

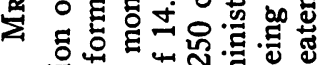
人

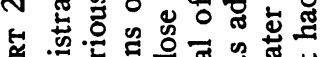

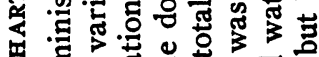

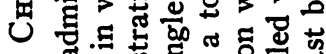

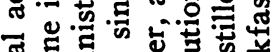
단. 엉톨

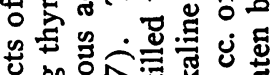

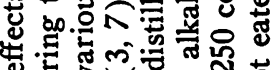
की 5 कर o. o n.: 5 of 5 क.

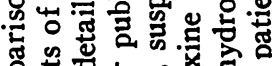

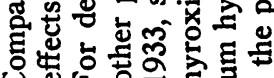

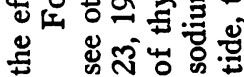




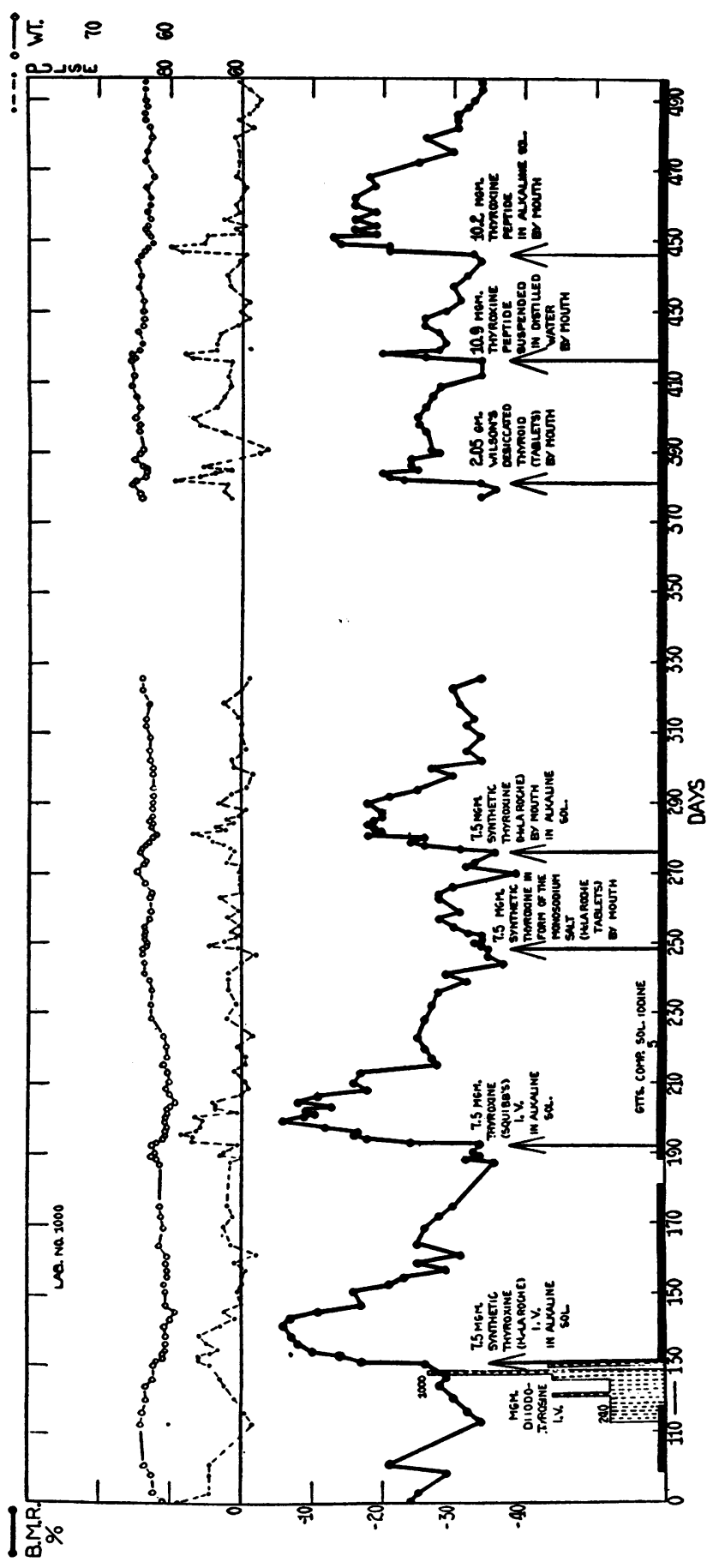



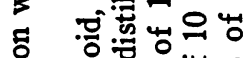

吾

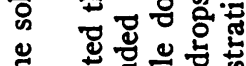

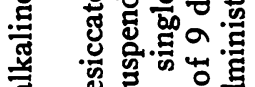

नै कै के

픔

नै ही

密.

3 형

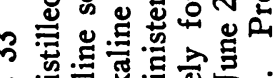

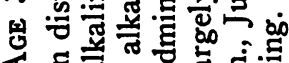

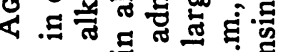

讨.

है च्च

8 要

क

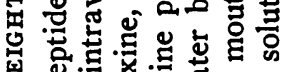

出

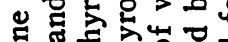

我荠

<

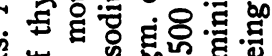

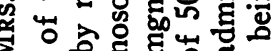

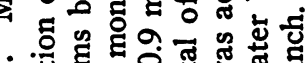

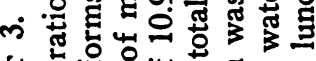

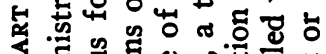

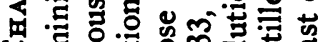

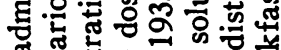

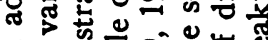
西. E.:

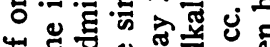

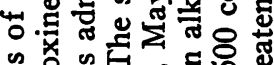
里 은

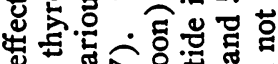
ॠ. 山ै 政

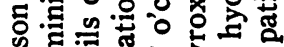

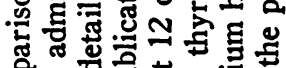

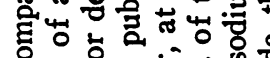

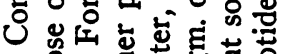

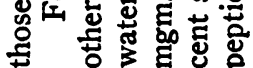


In the second and third patients we have also observed the effects of administering single large doses of thyroxine in alkaline solution intravenously and equivalent doses of desiccated thyroid by mouth. In these two patients it may be calculated that for doses containing $6.5 \mathrm{mgm}$. of iodine, the intravenous administration of thyroxine in alkaline solution produced an average increase in the basal metabolism from minus 29 per cent to minus 2 per cent, and the oral administration of desiccated thyroid an increase from minus 31 per cent to minus 14 per cent, as compared with an increase from minus 31 per cent to minus 7 per cent for oral administration of the peptide in alkaline solution. The average increases produced by oral administration of the peptide suspended in distilled water and the monosodium salt of thyroxine were nearly the same for these two patients as for all three patients. Thus, the effect of administering single

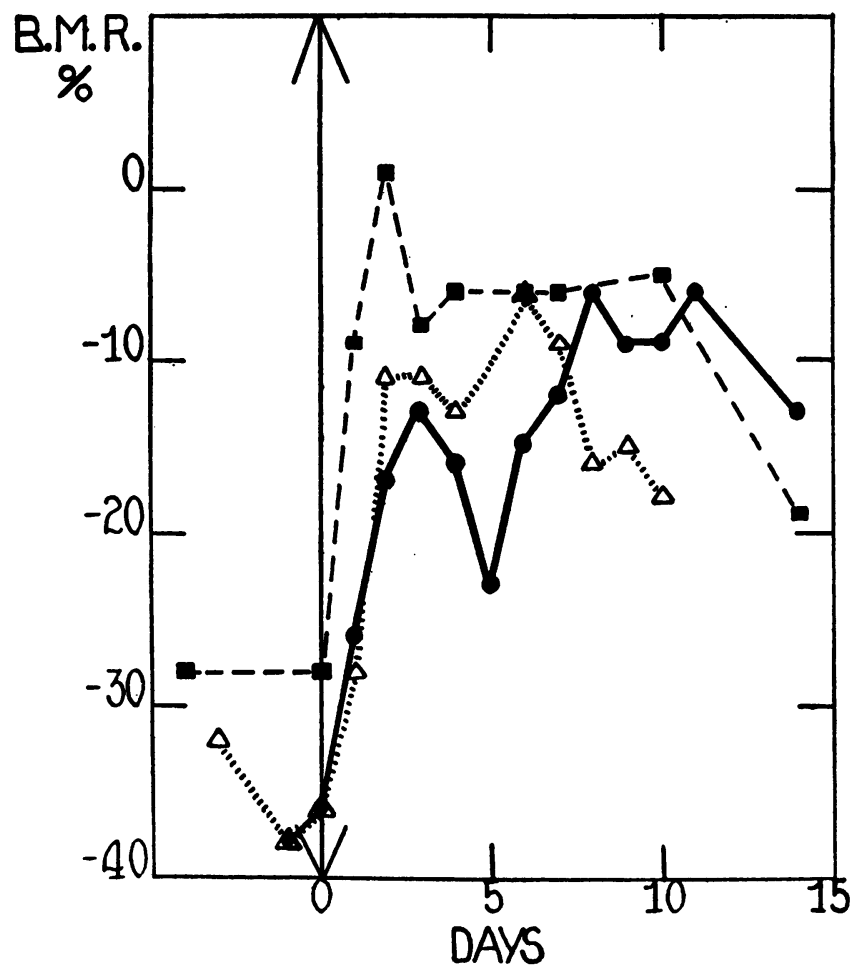

Chart 4

Comparison of the effect on the basal metabolism observed by Salter, Lerman and Means (9) from oral administration of $13.0 \mathrm{mgm}$. of their peptide containing $6.5 \mathrm{mgm}$. of iodine to one patient with myxedema (white triangles) with that observed by us from oral administration of an alkaline solution of $13.5 \mathrm{mgm}$. of our peptide containing $6.5 \mathrm{mgm}$. of iodine to two patients with myxedema (black circles, the first patient; black squares, the second patient). 


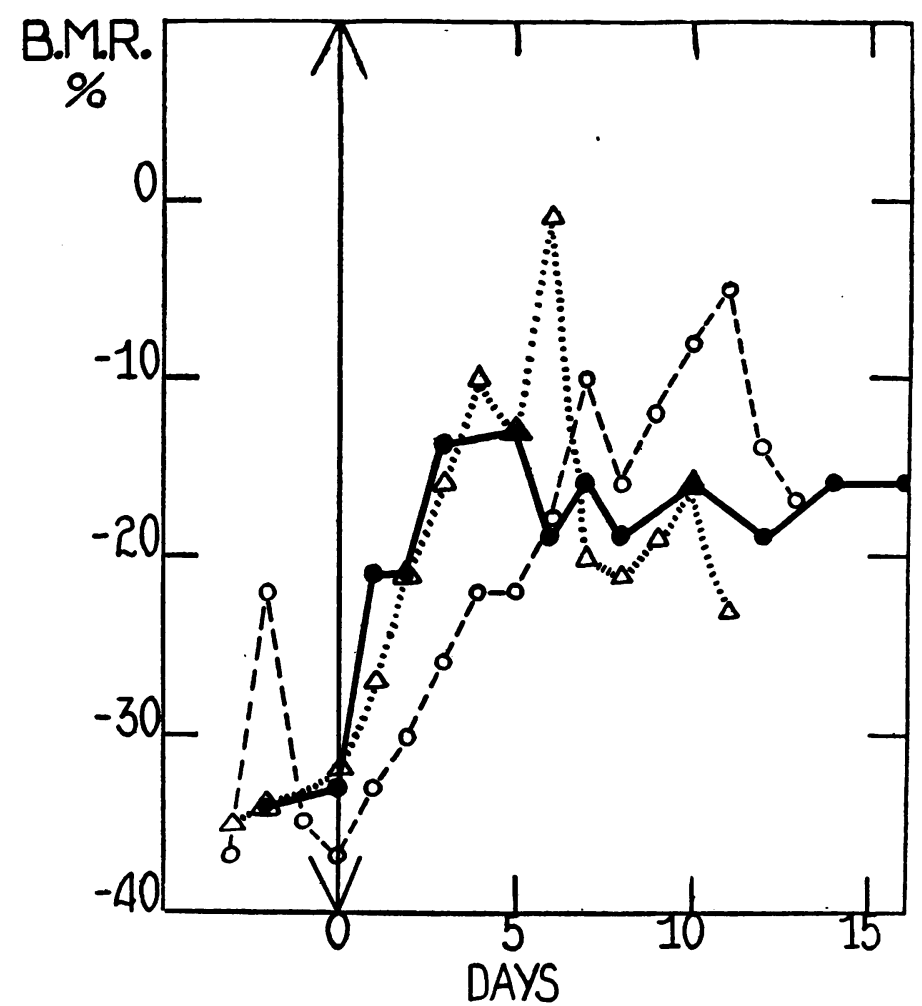

Chart 5

Comparison of the effects on basal metabolism observed by Salter, Lerman and Means (9) from oral administration of $10.0 \mathrm{mgm}$. of their peptide containing $4.9 \mathrm{mgm}$. of iodine to two patients with myxedema (interrupted lines) with those observed by us from oral administration of an alkaline solution of 10.2 mgm. of our peptide containing $4.9 \mathrm{mgm}$. of iodine to one patient with myxedema (solid line, the third patient).

large doses of peptide by mouth in alkaline solution was nearly the same as that of administering single large doses of thyroxine in alkaline solution intravenously, but was greater than that of administering single large doses of desiccated thyroid by mouth. However, the effect of desiccated thyroid was about twice as great as that produced by oral administration of the peptide suspended in distilled water or that produced by oral administration of the monosodium salt of thyroxine.

Salter, Lerman and Means (9) have reported the effects of three separate oral administrations of their polypeptide- one of $13.0 \mathrm{mgm}$. containing $6.5 \mathrm{mgm}$. of iodine and two of $10.0 \mathrm{mgm}$. each containing $4.9 \mathrm{mgm}$. of iodine. By changing the effects to terms of $6.5 \mathrm{mgm}$. of iodine we have calculated that this dose of iodine administered by mouth in the form of 
their polypeptide would have produced an increase in the basal metabolism from minus 36 per cent to minus 6 per cent on the average, a change which is nearly the same as that produced by the oral administration of $6.5 \mathrm{mgm}$. of iodine in the form of our peptide $(13.5 \mathrm{mgm}$.) in alkaline solution. We have compared our data with theirs in Charts 4 and 5. It is of interest that their peptide was dissolved in an alkaline solution and the solution then neutralized.

It is of interest to combine the data of the present study with those which we have previously reported concerning the effects of the administration of thyroxine in various forms by the oral and intravenous routes. This has been done in Table II. It may be noted that, on the average, the increases in basal metabolism produced by the oral administration of single large doses of monosodium thyroxine, thyroxine peptide suspended in distilled water, pure thyroxine in alkaline solution, desiccated thyroid and thyroxine peptide in alkaline solution are respectively 22 per cent, 28 per cent, 63 per cent, 69 per cent and 78 per cent as great as those produced by the intravenous injection of an alkaline solution of single large doses of pure thyroxine containing the same amount of iodine. In terms of "excess calorie" production, the corresponding figures are 18, 18, 58, 48 and 54 per cent respectively.

\section{SUMMARY}

From a proteolytic digest of desiccated thyroid we have prepared a peptide of thyroxine containing 48 per cent iodine, with a nitrogen: iodine ratio of $0.48: 1$. This product is insoluble in distilled water but soluble in a dilute solution of sodium hydroxide.

When suspended in distilled water and administered by mouth to patients with myxedema it produced only a slight increase in the basal metabolism, which was about the same as that produced by oral administration of the monosodium salt of thyroxine in doses which contained the same amounts of iodine, and about one-quarter as great as that produced by thyroxine in alkaline solution given intravenously. However, when administered by mouth in an alkaline solution, the peptide produced a wellmarked increase in basal metabolism which was nearly four-fifths as great as that produced by thyroxine in alkaline solution given intravenously, and slightly greater than those produced by oral administration of desiccated thyroid and thyroxine in alkaline solution.

\section{BIBLIOGRAPHY}

1. Thompson, W. O., Thompson, P. K., Taylor, S. G., III, and Dickie, L. F. N., Oral and duodenal administration of single large doses of pure thyroxine: Comparison of calorigenic effects with those of monosodium thyroxine and thyroxine in alkaline solution. Arch. Int. Med. (In press.) 
2. Kendall, E. C., Thyroxine. The Chemical Catalog Company, Inc., New York, 1929.

3. Thompson, W. O., Thompson, P. K., Dickie, L. F. N., and Alper, J. M., Effect of alkali on the absorption of thyroxine from the gastro-intestinal tract, with a note on the comparative effects of synthetic and " natural" thyroxine injected intravenously. Arch. Int. Med., 1933, 52, 809.

4. Thompson, W. O., Thompson, P. K., Taylor, S. G., III, Alper, J. M., and Dickie, L. F. N., The effects of various compounds of thyroxine on the basal metabolism. Endocrinology, 1934, 18, 228.

5. Thompson, W. O., Thompson, P. K., and Dickie, L. F. N., Monosodium thyroxine, desiccated thyroid and an impure sodium salt of thyroxine. Comparison of their effects when administered orally with the effect of thyroxine injected intravenously in an alkaline solution. Arch. Int. Med., 1933, 52, 576.

6. Thompson, W. O., Thompson, P. K., Dickie, L. F. N., and Taylor, S. G., III, The iodine in the thyroid gland. West. J. Surg., 1933, 41, 431.

7. Thompson, W. O., Thompson, P. K., Taylor, S. G., III, and Dickie, L. F. N., The calorigenic action of single large doses of desiccated hog thyroid: Comparison with that of thyroxine given orally and intravenously. Arch. Int. Med. (In press.)

8. Harington, C. R., and Salter, W. T., The isolation of 1-thyroxine from the thyroid gland by the action of proteolytic enzymes. Biochem. J., 1930 , $24,456$.

9. Salter, W. T., Lerman, J., and Means, J. H., The calorigenic action of thyroxin polypeptide. J. Clin. Invest., 1933, 12, 327.

10. Leland, J. P., and Foster, G. L., A method for the determination of thyroxine in the thyroid. J. Biol. Chem., 1932, 95, 165.

11. Folin, O., with the assistance of $\mathrm{Wu}, \mathrm{H}$., A system of blood analysis. Sup. plement III. A new colorimetric method for the determination of the amino-acid nitrogen in blood. J. Biol. Chem., 1922, 51, 377.

12. Thompson, W. O., Thompson, P. K., Brailey, A. G., and Cohen, A. C., The calorigenetic action of thyroxin at different levels of basal metabolism in myxedema. J. Clin. Invest., 1929, 7, 437. 